\title{
Effect of a Post-Anthesis Foliar Application of Nitrogen on Grain Protein and Milling and Baking Quality of Spring Wheat
}

\author{
Joel Ransom¹, Senay Simsek¹, Blaine Schatz ${ }^{2}$, Eric Eriksmoen ${ }^{3}$, Grant Mehring1, Itai Mutukwa1 \\ ${ }^{1}$ Department of Plant Sciences, North Dakota State University, Fargo, ND, USA \\ ${ }^{2}$ Carrington Research Extension Center, North Dakota State University, Carrington, ND, USA \\ ${ }^{3}$ North Central Research Extension Center, North Dakota State University, Minot, ND, USA \\ Email: joel.ransom@ndsu.edu
}

How to cite this paper: Ransom, J., Simsek, S., Schatz, B., Eriksmoen, E., Mehring, G. and Mutukwa, I. (2016) Effect of a PostAnthesis Foliar Application of Nitrogen on Grain Protein and Milling and Baking Quality of Spring Wheat. American Journal of Plant Sciences, 7, 2505-2514.

http://dx.doi.org/10.4236/ajps.2016.717218

Received: November 16, 2016

Accepted: December 24, 2016

Published: December 27, 2016

Copyright $\odot 2016$ by authors and

Scientific Research Publishing Inc.

This work is licensed under the Creative

Commons Attribution International

License (CC BY 4.0).

http://creativecommons.org/licenses/by/4.0/

\begin{abstract}
Hard red spring wheat in North America must be high in protein in order to avoid costly discounts when marketed. Many newer cultivars have higher yield potential but produce relatively lower grain protein levels. A post-anthesis foliar application of urea-ammonium nitrate mixed with equal part water at $33 \mathrm{~kg} \cdot \mathrm{ha}^{-1}$ nitrogen $(\mathrm{N}) \mathrm{can}$ increase grain protein levels by up to one percent. This increase can be profitable when market premiums/discounts for protein are moderate to high. Nitrogen applied post-anthesis consistently increased grain protein content more than the application of the same rate of $\mathrm{N}$ to the soil prior to planting. Milling and baking analysis reveals augmenting the protein in this way does not diminish its functionality.
\end{abstract}

\section{Keywords}

Bread Wheat, Loaf Volume, Yield, Protein Functionality, Nitrogen Fertilization

\section{Introduction}

Grain protein concentration is an important factor when marketing hard red spring wheat (HRSW). High protein content is associated with increased gluten strength and loaf volumes thus superior milling and baking quality [1]. In the Upper Midwest of the USA, the standard market grain protein content for hard red winter wheat (HRWW) and HRSW is $120 \mathrm{~g} \cdot \mathrm{kg}^{-1}$ and $140 \mathrm{~g} \cdot \mathrm{kg}^{-1}$, respectively [2]. When producers do not meet these market standards, they might receive discounted prices, while a premium might be paid for grain protein concentration above $140 \mathrm{~g} \cdot \mathrm{kg}^{-1}$. The extent of these discounts and premiums vary greatly from year to year, and within the year, with the greatest 
price fluctuations usually occurring a few weeks after spring wheat harvest when the quality of the crop becomes widely known. During the last ten years, when compared to $140 \mathrm{~g} \cdot \mathrm{kg}^{-1}$ protein, discounts have varied from zero to $\$ 1.90$ per bushel $(27.2 \mathrm{~kg}$ ) for $130 \mathrm{~g} \cdot \mathrm{kg}^{-1}$ protein wheat and premiums from zero to $\$ 1.60$ per bushel $(27.2 \mathrm{~kg})$ for 150 $\mathrm{g} \cdot \mathrm{kg}^{-1}$ protein wheat at the Portland (Oregon) export terminal [3].

Nitrogen is an expensive input that significantly impacts both grain yield and protein concentration [4]. The nitrogen use efficiency (NUE) of cereal crops worldwide is only about $33 \%$, as the majority of the applied $\mathrm{N}$ is lost due to leaching, erosion, nitrification or volatilization [5]. Maximizing NUE is important for both economic and environmental reasons [6]. Wheat producers in North Dakota and Minnesota typically apply all of the $\mathrm{N}$ fertilizers pre-plant or at seeding [7]. Many spring wheat cultivars that are now being used by growers in the USA have higher yield potential but a lower grain protein content potential. The relationship between yield potential and grain protein is negative with few exceptions that deviate only marginally from the trend line [8]. One technique that has been developed to improve the protein content is a foliar application of nitrogen shortly after flowering [2] [9]. The current recommendation is to apply a mix of water and urea-ammonium nitrate (UAN) solution ( $28 \%$ nitrogen by weight) at a rate of $33 \mathrm{~kg} \mathrm{~N} \mathrm{ha}^{-1}$ a few days after flowering during the cool of the day using spray nozzles that are normally used for fungicides or herbicides (i.e. flat fans).

The milling and baking industry in the USA have raised questions regarding the functionality of the protein in grain that has received a foliar application of nitrogen post-flowering. Several milling, dough handling, and baking properties are important for the end users of HRSW [10] [11]. Grain volume weight, 1000-kernel weight, and flour extraction yield are some indicators of milling quality [12]. Some indicators of baking quality include water absorption, mixing time, mixing tolerance, loaf volume, loaf crumb grain, and crumb color [13]. The objective of this work was to determine the effect of a post-anthesis foliar application of UAN on protein quantity and functionality in HRSW.

\section{Materials and Methods}

\subsection{Field Experiments}

Field experiments were conducted from 2011 to 2013 at the Carrington and North Central Research Extension Centers (CREC and NCREC) of the North Dakota State University Agricultural Experiment Station and near the town of Prosper, North Dakota. Normal temperature and rainfall for the growing season (typically 15 April to 15 August) are 15, 14, and 17 degrees C. and 230, 209 and $250 \mathrm{~mm}$ for CREC, NCREC and Prosper, respectively. Experiments consisted of a factorial combination of nitrogen fertilizer treatments and cultivars laid out in a randomized complete block design with four replications. Planting and base fertilization dates varied from about 15 April to 15 May depending on the location and season but were generally as early in the spring as was practical given the condition of the soil. Nitrogen fertilizer treatments consisted of 
$75 \%$ of the recommend rate applied as urea at planting, $75 \%$ of the recommended nitrogen rate plus $33 \mathrm{~kg} \cdot \mathrm{ha}^{-1}$ additional nitrogen applied as urea at planting, and $75 \%$ of the recommended nitrogen rate applied as urea at planting plus $33 \mathrm{~kg} \cdot \mathrm{ha}^{-1}$ of $\mathrm{N}$ as a foliar application of a 1:1 mixture of water and urea ammonium nitrate (UAN) which contained $28 \%$ nitrogen by weight. This was applied at $187 \mathrm{~L} \cdot \mathrm{ha}^{-1}$ of total solution using flat fan nozzles. $75 \%$ of the recommended nitrogen rate was used in this experiment in an attempt to produce a crop that had sufficient nitrogen for high yield development, but which would likely produce grain that had less than $14 \mathrm{~g} \cdot \mathrm{kg}^{-1}$ protein. This would allow us to better duplicate the circumstance that many farmers encounter: high yields but low protein. It would also enable us to have adequate differences between treatments for protein so that we could determine if the added protein from a foliar application of $\mathrm{N}$ has similar functionality to the protein produced with conventional nitrogen application practices. We limited our foliar application rate of UAN to just one rate, 33 $\mathrm{kg} \cdot \mathrm{ha}^{-1}$ of nitrogen, because previous research had shown that higher rates caused significant leaf burn and yield loss, while lower rates did not increase protein levels optimally. The varieties used in this study were Barlow, Faller, Glenn and RB07. Barlow, Faller and Glenn are varieties that were developed at North Dakota State University and released by the North Dakota Agricultural Experiment Station. RB07 was developed and released by the University of Minnesota Experiment Station. These varieties are relatively recent releases, grown widely in the region, and varied in their yield potential and the grain protein in a given environment. Faller has the highest yield potential and the lowest grain protein while Glenn has the lowest yield potential but the highest grain protein. The other two varieties were intermediate for both yield and grain protein content. Experiments were planted near the optimum planting date for the growing season and location. Weeds were controlled with recommended herbicides. Plots consisted of seven rows of wheat with an $18 \mathrm{~cm}$ spacing and were 3.7 to $7.6 \mathrm{~m}$ in length depending on the location. Plots were harvested by a combine and samples were cleaned before being weighed and subject to further analysis. Grain protein was measured with near infrared spectroscopy, using a hard spring wheat calibration.

\subsection{Milling and Baking Quality Analysis}

Due to the expense and quantity of grain required, milling and baking analysis could not be performed on all experimental units. In 2011, grain from all replications for a given treatment and location were combined and locations were considered as the blocks in the analysis of variance. In 2012, the harvested grain from replicates one and two and replicates three and four were combined for a given treatment in Minot and only the experimental units from replicates one and two were used from Prosper. In 2013, grain from replicates one and two and replicates three and four were combined at each location (Carrington, Minot and Prosper). When grain from replicates were combined, they were thoroughly mixed prior to final cleaning on a Clipper grain cleaner (Clipper Separation Technologies, Bluffton, IN) and a Carter Dockage machine (Carter-Day Co., Minneapolis, MN). 
The following analyses were performed on $150 \mathrm{~g}$ subsamples of the composite sample previously described in each experiment. Moisture content was determined using a Motomco moisture meter (Motomco Inc., Paterson, NJ) according to Approved Method 39 - 25.01 [14]. Samples were pretempered to a moisture basis of $125 \mathrm{~g} \cdot \mathrm{kg}^{-1}$ grain and tempered to moisture basis of $160 \mathrm{~g} \cdot \mathrm{kg}^{-1}$ grain for 18 to $20 \mathrm{~h}$ before milling according to Approved Method 26-21.02 [14]. Grain (1 kg) was milled using a Buhler Laboratory mill (Type MLU-202, Buhler Industries, Inc Uzwil, Switzerland) to determine flour extraction (\%). Grain volume weight was determined according to Approved Method 55 - 10 [14]. Thousand kernel weight (g) was determined based on the weight of $10 \mathrm{~g}$ sample of cleaned wheat counted on an electric seed counter (Seedburo Equipment Co., Chicago, IL). Grain protein content $\left(\mathrm{g} \cdot \mathrm{kg}^{-1}\right)$ was determined for each plot sample on a whole grain basis at $12.0 \%$ moisture content using Tecator Infratec 1226 Grain Analyzer (Foss, Eden Prairie, MN) according to Approved Method 39 10.01 [14].

Dough functionality was conducted with the following methods. Wet gluten percentage was calculated on a $14 \%$ moisture basis according to Approved Method 38.12 .02 [14] with a Glutomatic system (Perten Instruments, Kungens Kurva, Sweden). Falling number method 56.81 .03 [14] was conducted to determine preharvest sprouting (Perten Instruments, Kungens Kurva, Sweden).

Dough quality was assessed with Farinograph (C.W. Brabender Instruments Inc, New Hackensack NJ) according to Approved Method 54 - 21.02 [14] utilizing a Farinograph $\mathrm{E}$ and $50 \mathrm{~g}$ removable blade bowl. Farinograph absorption, peak time, and stability were determined.

Baking tests $(100 \mathrm{~g})$ were done according to Approved Method 10 - 09.01 (Experimental Bread Baking Long Fermentation) [14] to determine flour water absorption (\%), loaf volume (cc), crumb color (1 - 10), and crust color (1 - 10). Baking absorption is the amount of water required to hydrate flour components into an optimally developed dough mass with specific consistency. Baking absorption was expressed as a percent of flour with a high percentage being desirable. The higher the baking absorption, the greater the dough and bread yield. Dough character refers to the handling properties at the punching and panning stages and was expressed on a scale from 1 to 10 with the higher score being the most desirable. The loaf volume refers to the volume, expressed in cubic centimeters (cc), of the experimental $100 \mathrm{~g}$ loaf. A high loaf volume is considered desirable. Crumb color of the internal loaf of bread was subjectively measured against a standard, and was expressed on a scale from 1 to 10 with the highest score being the most desirable. Crust color of the external loaf of bread was subjectively measured against a standard and was expressed on a scale from 1 to 10 with the highest score being the most desirable.

Data were subjected to an analysis of variance (ANOVA) using Proc GLM and Proc Corr in SAS [version 9.3] (SAS Institute, 2015). Difference in means were separated using an $\operatorname{LSD}(\mathrm{P}=0.05)$. 


\section{Results}

\subsection{Agronomic Performance}

The environmental conditions (locations and years) of the experiments varied with below average rainfall in Carrington (209, 175, and $156 \mathrm{~mm}$ for 2011, 2012 and 2013, respectively); above average rainfall in Minot in 2011 (290 mm) and $2013(413 \mathrm{~mm})$ and below average in $2012(180 \mathrm{~mm})$. Rainfall at Prosper over the three years had a similar trend to that of Minot. Temperatures were near normal for all locations and years. Moisture stress, either too little or too much, impacted yield and protein.

The yield and grain protein content varied considerably across locations and years due to environmental differences. Averaged across environments within a year, grain yield was modest, and at most locations below what was expected at the time of planting (Table 1). In all but the Prosper location in 2013, protein levels exceeded the $140 \mathrm{~g}$. $\mathrm{kg}^{-1}$ market threshold, even in treatments with $75 \%$ of the optimum nitrogen rate. In some locations the yields were low due to environmental stress, resulting in elevated levels of protein $\left(>160 \mathrm{~g} \cdot \mathrm{kg}^{-1}\right)$. When other factors become more limiting than nitrogen (water stress for example), fertility management had little or no impact on yield and/or protein. There was no cultivar by fertility management interaction for any of the agronomic traits analyzed. Cultivars varied significantly in their yield and protein levels (Table 1). As expected, Glenn was the lowest yielding of the cultivars and had the highest protein content each year. Faller, on the other hand generally was the highest yielding and had the lowest grain protein content except in 2013 when there was no significant difference between varieties for protein.

Fertilizer treatment significantly impacted yield and grain protein content (Table 2). Differences in yield were minimal, suggesting that nitrogen was adequate for yield at the $75 \%$ optimum $\mathrm{N}$ rate. This response could be explained by the yields being modest relative to the expected yield and base fertilization rates used. Grain protein content increased as additional nitrogen was applied, whether as UAN in a post-anthesis (PA) application or as urea prior to planting (PP). The PA application produced more grain protein content than the PP application in each year of the study (Table 2). This suggests that the PA application method is a more efficient way to increase protein per unit

Table 1. Effect of cultivar on yield and grain protein content, averaged over nitrogen management treatments and locations, 2011-2013 .

\begin{tabular}{ccccccc}
\hline & \multicolumn{3}{c}{ Protein $\left(\mathbf{g} \cdot \mathbf{k g}^{-1}\right)$} & \multicolumn{3}{c}{ Yield (kg.ha $\left.{ }^{-1}\right)$} \\
\hline Cultivar & 2011 & 2012 & 2013 & 2011 & 2012 & 2013 \\
\hline Glenn & $160 \mathrm{a}$ & $157 \mathrm{a}$ & $149 \mathrm{a}$ & $2690 \mathrm{~b}$ & $3430 \mathrm{~b}$ & $2900 \mathrm{c}$ \\
Barlow & $156 \mathrm{~b}$ & $157 \mathrm{a}$ & $150 \mathrm{a}$ & $3040 \mathrm{a}$ & $3530 \mathrm{a}$ & $3120 \mathrm{~b}$ \\
RB07 & $146 \mathrm{c}$ & $155 \mathrm{a}$ & $146 \mathrm{a}$ & $2330 \mathrm{c}$ & $3540 \mathrm{a}$ & $3180 \mathrm{~b}$ \\
Faller & $146 \mathrm{c}$ & $152 \mathrm{~b}$ & $148 \mathrm{a}$ & $2930 \mathrm{a}$ & $3660 \mathrm{a}$ & $3470 \mathrm{a}$ \\
\hline
\end{tabular}

${ }^{\mathrm{a}}$ Means followed by the same letter are not significantly different at the 0.05 level of probability using the LSD method. 
Table 2. Effect of nitrogen fertilizer management on yield and grain protein content, averaged over cultivars, locations and years ${ }^{\mathrm{a}}$.

\begin{tabular}{|c|c|c|c|c|c|c|}
\hline \multirow[t]{2}{*}{ Fertilizer treatment } & \multicolumn{3}{|c|}{ Yield $\left(\mathrm{kg} \cdot \mathrm{ha}^{-1}\right)$} & \multicolumn{3}{|c|}{ Grain Protein Content $\left(\mathrm{g} \cdot \mathrm{kg}^{-1}\right)$} \\
\hline & 2011 & 2012 & 2013 & 2011 & 2012 & 2013 \\
\hline $75 \%$ optimal $N$ rate & $2819 a$ & $3456 \mathrm{a}$ & $3220 \mathrm{a}$ & $151 \mathrm{c}$ & $150 \mathrm{c}$ & $140 \mathrm{c}$ \\
\hline $\begin{array}{c}\text { 75\% optimal N rate + } \\
33 \mathrm{~kg} \cdot \mathrm{ha}^{-1} \mathrm{PA}^{\mathrm{b}}\end{array}$ & $2667 \mathrm{ab}$ & $3302 \mathrm{a}$ & $3011 \mathrm{~b}$ & $159 \mathrm{a}$ & $156 \mathrm{a}$ & $146 \mathrm{a}$ \\
\hline $\begin{array}{c}75 \% \text { optimal N rate + } \\
33 \mathrm{~kg} \cdot \mathrm{ha}^{-1} \mathrm{PP}^{\mathrm{c}}\end{array}$ & $2638 \mathrm{~b}$ & 3419 a & $3210 \mathrm{a}$ & $155 \mathrm{~b}$ & $152 \mathrm{~b}$ & $145 \mathrm{~b}$ \\
\hline
\end{tabular}

${ }^{a}$ Means followed by the same letter are not significantly different at the 0.05 level of probability using the LSD me-

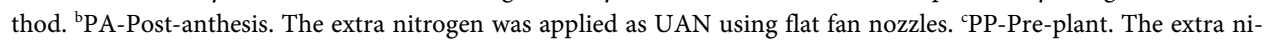
trogen was applied as urea prior to planting and incorporation.

of applied nitrogen than applying additional nitrogen at the time of planting. As with previous research, a PA of nitrogen at the recommended rate of $33 \mathrm{~kg} \cdot \mathrm{ha}^{-1} \mathrm{did}$ not improve yield and in fact, in our study, slightly decreased yield. Since there is a significant application cost associated with the PA application relative to applying additional nitrogen prior to planting, the monetary returns to this treatment will depend on the value of the protein and the overall yield of the crop.

\subsection{Milling and Baking Parameters}

In 2011 and 2012 for most of the milling and baking variables measured there were no significant fertilizer treatment effects (data not shown). This was largely due to the small number of experimental units in the analysis and the very high levels of protein; differences in protein functionality are more difficult to detect when protein levels are greater than $150 \mathrm{~g} \cdot \mathrm{kg}^{-1}$. Furthermore, when all of the data were included in the analysis, grain protein content was significantly correlated with milling and baking traits with the exception of flour ash and mixing time. Protein levels in 2013 were more in line with the range of proteins achieved by farmers, therefore the focus of the remaining analysis on the impact of fertility management and variety will be with those data. Since only a few of the variables measured were significantly impacted by the treatments included in this experiment, only those variables will be discussed.

There was no cultivar by fertilizer treatment interaction for any of the quality parameters measured (data not shown). However, cultivars differed significantly for several key milling and baking traits (Table 3). Flour protein did not differ significantly between Glenn, Barlow and RB07. All cultivars had more protein than Faller, however. Faller had the highest percentage of flour extraction, while Barlow had the highest wet gluten and baking absorption percentages. Glenn produced the largest loaf volume and Faller the smallest.

Similar to what was observed with regards to protein in the previously discussed agronomic section, additional nitrogen fertilization increased flour protein with the PA application of extra nitrogen being higher than the PP application (Table 4). The PP 
Table 3. Effect of cultivar on selected milling and baking parameters, $2013^{\mathrm{a}}$.

\begin{tabular}{cccccc}
\hline Cultivar & $\begin{array}{c}\text { Flour protein } \\
\left(\mathrm{g} \cdot \mathrm{kg}^{-1}\right)\end{array}$ & $\begin{array}{c}\text { Flour } \\
\text { Extraction }(\%)\end{array}$ & $\begin{array}{c}\text { Wet gluten } \\
(\%)\end{array}$ & $\begin{array}{c}\text { Baking } \\
\text { absorption }(\%)\end{array}$ & $\begin{array}{c}\text { Loaf volume } \\
(\mathrm{cc})\end{array}$ \\
\hline Glenn & $143 \mathrm{a}$ & $70.6 \mathrm{~b}$ & $38.9 \mathrm{~b}$ & $71.1 \mathrm{~b}$ & $1013 \mathrm{a}$ \\
Barlow & $142 \mathrm{a}$ & $71.0 \mathrm{~b}$ & $40.5 \mathrm{a}$ & $73.3 \mathrm{a}$ & $950 \mathrm{~b}$ \\
RB07 & $144 \mathrm{a}$ & $69.5 \mathrm{c}$ & $40.5 \mathrm{a}$ & $72.8 \mathrm{a}$ & $963 \mathrm{~b}$ \\
Faller & $133 \mathrm{~b}$ & $71.8 \mathrm{a}$ & $37.1 \mathrm{c}$ & $71.6 \mathrm{~b}$ & $925 \mathrm{c}$ \\
\hline
\end{tabular}

${ }^{\mathrm{a}}$ Means followed by the same letter are not significantly different at the 0.05 level of probability using the LSD method.

Table 4. Effect of nitrogen management on selected milling and baking parameters, Prosper location, $2013^{\mathrm{a}}$.

\begin{tabular}{|c|c|c|c|c|c|}
\hline Fertilizer treatment & $\begin{array}{l}\text { Flour protein } \\
\quad\left(g \cdot \mathrm{kg}^{-1}\right)\end{array}$ & $\begin{array}{c}\text { Flour } \\
\text { extraction (\%) }\end{array}$ & Wet gluten (\%) & $\begin{array}{c}\text { Baking } \\
\text { absorption (\%) }\end{array}$ & $\begin{array}{c}\text { Loaf } \\
\text { volume (cc) }\end{array}$ \\
\hline $75 \%$ optimal $\mathrm{N}$ rate & $137 \mathrm{c}$ & $70.9 \mathrm{ab}$ & $37.9 \mathrm{~b}$ & $71.6 \mathrm{~b}$ & $936 \mathrm{~b}$ \\
\hline $\begin{array}{c}75 \% \text { optimal } \mathrm{N} \text { rate }+ \\
33 \mathrm{~kg} \cdot \mathrm{ha}^{-1} \mathrm{PA}^{\mathrm{b}}\end{array}$ & $145 \mathrm{a}$ & $70.3 \mathrm{~b}$ & $40.4 \mathrm{a}$ & $72.6 \mathrm{a}$ & $980 \mathrm{a}$ \\
\hline $\begin{array}{c}75 \% \text { optimal } \mathrm{N} \text { rate }+ \\
33 \mathrm{~kg} \cdot \mathrm{ha}^{-1} \mathrm{PP}^{\mathrm{c}}\end{array}$ & $140 \mathrm{~b}$ & $71.1 \mathrm{a}$ & $39.7 \mathrm{a}$ & $72.3 \mathrm{a}$ & 978 a \\
\hline
\end{tabular}

${ }^{a}$ Means followed by the same letter are not significantly different at the 0.05 level of probability using the LSD me-

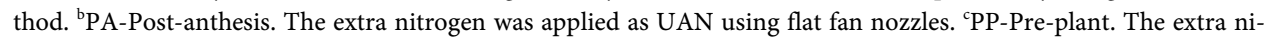
trogen was applied as urea prior to planting and incorporation.

treatment, however, had higher flour extraction compared to the PA treatments. Trends in wet gluten, baking absorption, and loaf volume were related to protein content, with the highest values in the $75 \%$ optimal $\mathrm{N}$ rate with the added $\mathrm{N}$ applied PA.

The relationship between protein content and milling and baking parameters were consistently high regardless of fertility treatment. It is therefore difficult to separate out the effect of quality from quantity. We used regression analysis of the data from Prosper in 2013 in order to determine if grain with similar protein contents but with differing fertility management had similar functionality (Figure 1). In this case we used loaf volume as a surrogate for protein quality, since it integrates most of the other quality traits into its outcome. From this relatively small data set, it appears that grain protein from plots that were treated with UAN PA produced similar loaf volumes to other treatments at a similar protein level; four of the PA observations were below the trend line, three were above the trend line and one was on the trend line.

\section{Discussion}

The post-anthesis application of UAN combined with water at a nitrogen rate of $33 \mathrm{~kg}$. $\mathrm{ha}^{-1}$ was found to be effective in increasing the grain protein content of hard red spring wheat. This addition of nitrogen to the crop had little or no impact on grain yield. Adding the same amount of nitrogen to the soil prior to planting (basically adding an additional $33 \mathrm{~kg} \cdot \mathrm{ha}^{-1}$ of nitrogen to the initial amount applied at or prior to planting) 


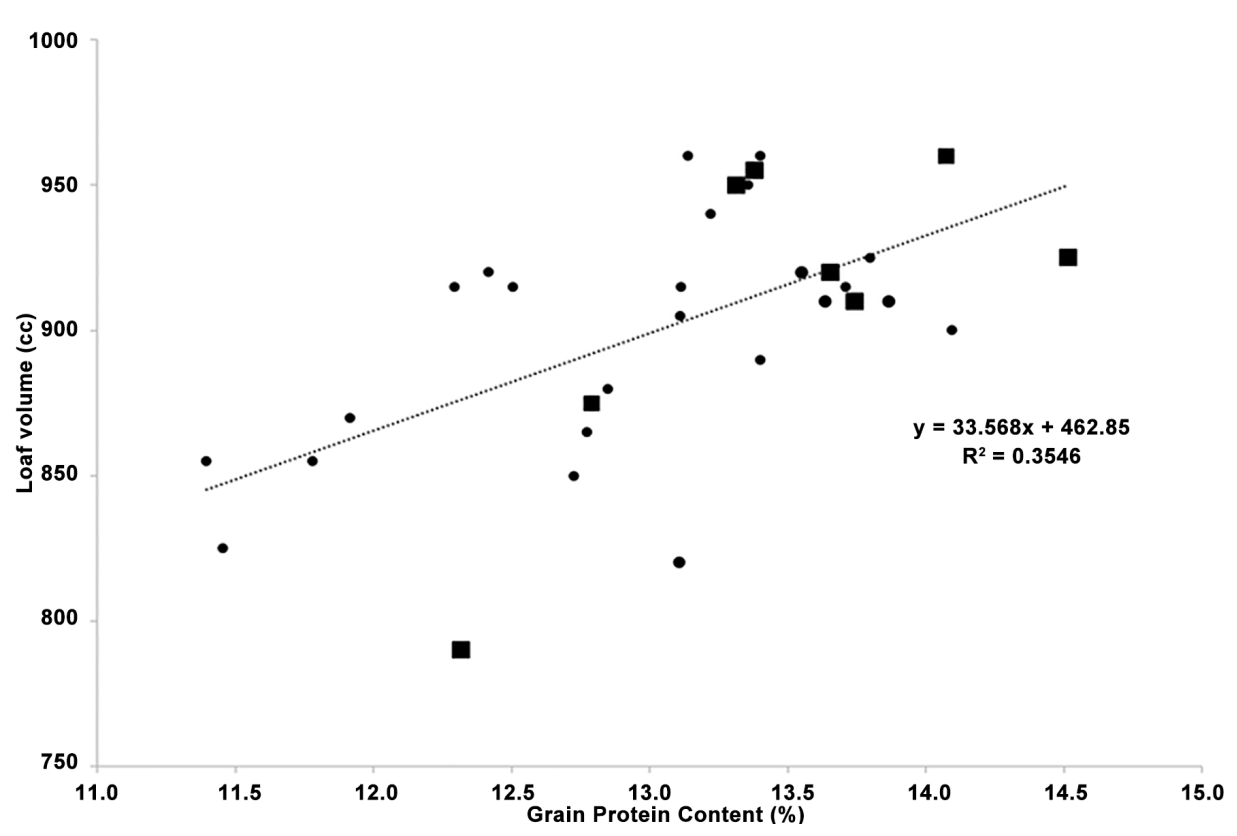

Figure 1. Relationship between grain protein content and loaf volume, Prosper ND, 2013. Individual points represent experimental units. Those indicated with “ $\mathbf{\square}$ " are data from the $75 \%$ optimum nitrogen $+33 \mathrm{~kg}$ ha- $1 \mathrm{~N}$ applied post-anthesis treatment.

also improved grain protein, but to a lesser extent than the foliar application. The actual recovery of the applied nitrogen that ended up in the grain was not calculated, but the data do suggest that the efficiency of fertilizer nitrogen to increase grain protein is greater with a foliar application than with a soil application. The level of protein increase by this treatment was somewhat less than reported by others who have conducted similar studies. However, we may have been attempting to augment protein levels in experiments where the protein level was already substantial. We speculate that it is more difficult to increase grain protein further when the protein level is at $150 \mathrm{~g} \cdot \mathrm{kg}^{-1}$ than it would be when attempting to increase the protein level of a wheat crop that contains $120 \mathrm{~g} \cdot \mathrm{kg}^{-1}$ protein.

Though the data we presented is somewhat limited due to the expense of conducting milling and baking tests, they strongly suggest that the quality of the grain with augmented protein as a result of a foliar application of UAN was similar to that using conventional nitrogen application approaches. The relationship between good bread making quality and high protein was quite tight and the method of achieving increased protein did not have a significant impact on this relationship. Our data also demonstrated the importance of variety choice in managing protein content and milling and baking quality. Many of the new, higher yielding cultivars have relatively less protein. These varieties, however, have become very popular due to the potential of increasing yields substantially. Nevertheless, in years when the protein premium/discount is high, the lower yielding, higher protein varieties are likely to be the most profitable. Furthermore, given the substantial additional expense of applying UAN post-anthesis, the profitability of this application will only be likely in situations where grain yield is high 
and protein premiums/discounts are significant. This practice should be considered as an effective tool for rescuing a field from low protein (within limits) when conditions warrant it, rather than as a standard practice to be used with all lower protein varieties.

\section{Conclusion}

A foliar application of UAN to spring wheat after flowering can increase the protein content of spring wheat consistently. The amount of protein increase with this treatment was consistently higher than that achieved with applying a similar amount of nitrogen at planting. Growers should carefully consider the economics of this practice, however, since it will not be profitable unless yield levels are quite high and when the protein premium/discount is also likely to be considerable (i.e. greater than $\$ 0.50$ per percent of protein above or below $140 \mathrm{~g} \cdot \mathrm{kg}^{-1}$ protein). Our data suggest that grain harvested from a field with a post-anthesis application of UAN has similar milling and baking characteristics of grain that has a similar level of protein without such treatment. More specifically the quality of the extra protein produced by this method has similar functionality to protein achieved through more traditional nitrogen management practices and therefore should be welcomed by the industry that requires high quality bread wheat.

\section{Acknowledgements}

We thank the North Dakota Wheat Commission for their financial support of this research.

\section{References}

[1] Busch, R.H., Shuey, W.C. and Frohberg, R.C. (1969) Response of Hard Red Spring Wheat (Triticum aestivum L.) to Environments in Relation to Six Key Quality Characteristics. Crop Science, 9, 813-817. https://doi.org/10.2135/cropsci1969.0011183X000900060044x

[2] Bly, A.G. and Woodard, H.J. (2003) Foliar Nitrogen Application Timing Influence on Grain Yield and Protein Concentration of Hard Red Winter and Spring Wheat. Agronomy Journal, 95, 335-338. https://doi.org/10.2134/agronj2003.0335

[3] Anon. (2016) Grain Market News, Weekly Edition. Livestock, Poultry and Grain Market News Division, USDA. https://www.ams.usda.gov/mnreports/lswpnwgrain.pdf

[4] Otteson, B.N., Mergoum, M. and Ransom, J.K. (2008) Seeding Rate and Nitrogen Management on Milling and Baking Quality of Hard Red Spring Wheat Genotypes. Crop Science, 48, 749-755. https://doi.org/10.2135/cropsci2007.08.0473

[5] Raun, W.R. and Johnson, G.V. (1999) Improving Nitrogen Use Efficiency for Cereal Production. Agronomy Journal, 91, 357-363. https://doi.org/10.2134/agronj1999.00021962009100030001x

[6] Mahler, R.L., Koehler, F.E. and Lutcher, L.K. (1994) Nitrogen Source, Timing of Application, and Placement: Effects on Winter Wheat Production. Agronomy Journal, 86, 637-642. https://doi.org/10.2134/agronj1994.00021962008600040010x

[7] Rehm, G. and Franzen, D. (2005) Fertility Management of Wheat. In: Wiersman, J.J. and Ransom, J.K., Eds., The Small Grains Field Guide, North Dakota State University and the University of Minnesota Extension Service, Fargo/St. Paul, 60-64. 
[8] Ransom, J.K., Mergoum, M., Simsek, S., Aceveda, M., Friesen, T., McMullen, M., Zhong, S., Olson, R., Eriksmoen, E., Hansen, B., Martin, G., Bradbury, G. and Schatz, B. (2012) North Dakota Hard Red Spring Wheat Variety Trail Results for 2012 and Selection Guide. Extension Publication A-574-12, North Dakota State University Extension Service, Fargo.

[9] Finney, K.F., Meyer, J.W., Smith, F.W. and Fryer, H.C. (1957) Effect of Foliar Spraying on Pawnee Wheat with Urea Solutions on Yield, Protein Concentration, and Protein Quality. Agronomy Journal, 49, 347-347. https://doi.org/10.2134/agronj1957.00021962004900070001x

[10] Guttieri, M.J., Ahmad, R., Stark, J.C. and Souza, E. (2000) End-Use Quality of Six Hard Red Spring Wheat Cultivars at Different Irrigation Levels. Crop Science, 40, 631-635. https://doi.org/10.2135/cropsci2000.403631x

[11] López-Bellido, L., Muñoz-Romero, V., Benítez-Vega, J., Fernández-García, P., Redondo, R. and López-Bellido, R.J. (2001) Wheat Response to Nitrogen Splitting Applied to a Vertisols in Different Tillage Systems and Cropping Rotations under Typical Mediterranean Climatic Conditions. European Journal of Agronomy, 43, 24-32.

https://doi.org/10.1016/j.eja.2012.05.002

[12] Finney, K.F., Yamazaki, W.T., Youngs, V.L. and Rubenthaler, G.L. (1987) Quality of Hard, Soft, and Durum Wheats. In: Heyne, E.G., Ed., Wheat and Wheat Improvement, 2nd Ed., Agronomy Monograph 13, ASA, CSSA, and SSSA, Madison, 677-748.

[13] Finney, K.F. (1965) Evaluation of Wheat Quality. In: Food Quality. Effects of Production Practices and Processing, Publication No. 77, AAAS, Washington DC, 73-82.

[14] American Association of Cereal Chemists International (2015) Approved Methods of the AACCI. 10th Edition, Methods 10-10B, 26-10A, 54-40A, 55-10, The Association, St. Paul, $\mathrm{MN}$.

\section{Submit or recommend next manuscript to SCIRP and we will provide best service for you:}

Accepting pre-submission inquiries through Email, Facebook, LinkedIn, Twitter, etc. A wide selection of journals (inclusive of 9 subjects, more than 200 journals)

Providing 24-hour high-quality service

User-friendly online submission system

Fair and swift peer-review system

Efficient typesetting and proofreading procedure

Display of the result of downloads and visits, as well as the number of cited articles

Maximum dissemination of your research work

Submit your manuscript at: http://papersubmission.scirp.org/

Or contactajps@scirp.org 